\title{
Local indigenous knowledge of salmea scandens (1.) Dc. (asteraceae), a medicinal and nutritional resource from oaxaca, Mexico
}

\section{Short title: ethnobotany of salmea scandens (1.) Dc. (asteraceae) in oaxaca, méxico}

\author{
DOI: $10.46932 / \mathrm{sfjdv} 2 \mathrm{n} 4-077$
}

Received in: May 1st, 2021

Accepted in: Jun 30th, 2021

\section{Olivia Maciel-Amador}

Instituto Politécnico Nacional, Centro Interdisciplinario de Investigación para el Desarrollo Integral Regional Unidad Oaxaca, Hornos 1003, Santa Cruz Xoxocotlán, 71230, Oaxaca, México.

\section{Rodolfo Solano Gomez}

Instituto Politécnico Nacional, Centro Interdisciplinario de Investigación para el Desarrollo Integral Regional Unidad Oaxaca, Hornos 1003, Santa Cruz Xoxocotlán, 71230, Oaxaca, México.

Corresponding author: asolanog@ipn.mx

Nadia Mabel-Pérez Vielma

Instituto Politécnico Nacional, Centro Interdisciplinario de Ciencias de la Salud Unidad Santo Tomás, México De los Maestros, Santo Tomás, 11340, Ciudad de México, México.

\section{Luicita Lagunez-Rivera}

Instituto Politécnico Nacional, Centro Interdisciplinario de Investigación para el Desarrollo Integral Regional Unidad Oaxaca, Hornos 1003, Santa Cruz Xoxocotlán, 71230, Oaxaca, México.

\begin{abstract}
Salmea scandens is a plant that grows in America tropics and is known for its medicinal and nutritional applications. Derived from local indigenous knowledge, the species is used for its analgesic properties, especially as remedy in dentistry in communities of the southern highlands of Oaxaca, Mexico. Important information on local knowledge and uses of $S$. scandens was gathered using a bibliographic review and with open and semi-structured interviews conducted in a Zapotec community in the Southern Mountains of Oaxaca. In the community studied people recognize and use two morphotypes of the plant that differentiate by the color of the bark (black and white). We reported two not documented uses for this species, one nutritional and one medicinal. In the nutritional form, the plant is used to season traditional dishes and as the main ingredient of other recipes. In medicinal uses, the plant treats dental pain, gastritis, and boils. Community prefer the white morphotype for nutritional use, but there is no preference for any of them for medicinal use. The medicinal use of S. scandens is related to problems that involve an inflammatory process, suggesting that the species has a potential in the search for new products to treat odontalgia.
\end{abstract}

Keywords: Central America ethnobotany, ethnomedicine, odontalgia, edible plants, medicinal plants.

\section{RESUMEN}

Salmea scandens es una planta que crece en los trópicos de América y es conocida por sus aplicaciones medicinales y nutricionales. Derivado del conocimiento indígena local, la especie se utiliza por sus propiedades analgésicas, especialmente como remedio en odontología en comunidades de las tierras altas del sur de Oaxaca, México. Se recopiló información importante sobre el conocimiento local y los usos de S. scandens mediante una revisión bibliográfica y con entrevistas abiertas y semiestructuradas realizadas 
en una comunidad zapoteca en las montañas del sur de Oaxaca. En la comunidad estudiada, las personas reconocen y usan dos morfotipos de la planta que se diferencian por el color de la corteza (blanco y negro). Reportamos dos usos no documentados para esta especie, uno nutricional y uno medicinal. En forma nutricional, la planta se utiliza para sazonar platos tradicionales y como ingrediente principal de otras recetas. En usos medicinales, la planta trata el dolor dental, la gastritis y los forúnculos. La comunidad tiene preferencia por el morfotipo blanco para uso nutricional, pero no hay preferencia por ninguno de ellos para uso medicinal. El uso medicinal de $S$. scandens está relacionado con problemas que implican un proceso inflamatorio, lo que sugiere que la especie tiene potencial en la búsqueda de nuevos productos para tratar la odontalgia.

\section{INTRODUCTION}

With more than 12,500 species of flora and fauna and 16 ethnic groups, Oaxaca is the state that hosts the greatest biological and cultural diversity in Mexico (García-Mendoza 2004; García-Vargas 2018; Ordóñez and Rodríguez 2008). The experiences acquired over time derived from the coexistence of these social groups with the biodiversity of their natural environment has generated traditional knowledge that is transmitted across generations and becomes part of their worldview and identity (Aguilar-Santelises and del Castillo 2015; Boege 2008; Luna-José and Aguilar 2012; ). However, sometimes this knowledge has been enriched over time with the incorporation of external elements from different civilizations, which can be reflected in the practices of use of certain biological resources in indigenous communities.

Salmea scandens (L.) DC is a climbing erect shrub of the Asteraceae family, distributed in America, from Mexico to southern Brazil and northern Argentina, including the Antilles (Bolick 1991; Villaseñor 2018). In Mexico, the species is distributed throughout the tropical zone of the country (Carnevali et al. 2012; Villaseñor 2016; 2018) and, depending on the region, it is known by the common names of tank'as aak (Mayan), chilmecate (Náhuatl), pinimayac (Totonac), and ix-tzaj (Huastec) (Bohlman et al. 1985; Guzmán 2010; Luna-José and Rendón-Aguilar 2008, 2012; Martínez 1994; VillaRuano et al. 2013; 2015). In southern mountain range of Oaxaca, the species is known with the names of "palo de chile" (chili stick), "hierba del pescado" (fish herb), "bejuco de chile" (chili bean), "duerme boca" (sleep mouth), and yaa yin (Zapotec) (Luna-José and Rendón-Aguilar; 2012). In American countries with presence of indigenous population, such as Mexico and Peru, medicinal and nutritional uses are reported for S. scandens (De Feo 2003; Luna-José and Rendón-Aguilar 2008; Pérez and GarcíaMorales 2016; Villa-Ruano et al. 2013; 2015), which is considered as local knowledge since it presents geographical differences between countries and regions of a country.

In Peru, the use of $S$. scandens is reported to treat vaginal bleeding, reverse female sterility, as a restorative, as well as to relieve cough, stomachache, body ache, hernias, bad air (low blood pressure), toothache, prolapse, and urinary conditions (De Feo 2003). In Mexico, documentation of the medicinal 
uses of S. scandens includes the following local reports: in Chiapas to treat gastrointestinal and respiratory diseases (Tortoriello et al. 1995); in Yucatan Peninsula to treat fever (Carnevali et al. 2012); in San Luis Potosí as an anti-inflammatory (Guzmán 2010); in Oaxaca for the treatment of diabetes, wild animal bites, toothaches, and inflammation (Luna-José and Rendón-Aguilar 2008; Pérez and García-Morales 2016; Villa-Ruano et al. 2013; 2015). A different use of the species is as construction material for living fences (Grossman 2003). In the southern region of Oaxaca, S. scandens also has relevance in the local diet (LunaJosé and Rendón-Aguilar 2008; Pérez and García-Morales 2016; Villa-Ruano et al. 2013; 2015). Pérez and García-Morales (2016) analyzed the nutritional content on a fresh plant basis, which includes raw fiber (10.9\%), fat (2.9\%), protein (4.9\%), and potassium (834.61 mg / 100). Meanwhile, a boiled sample contains raw fiber $(9.4 \%)$, fat (2.5\%), protein (3.1\%), and potassium $(505.53 \mathrm{mg} / 100 \mathrm{~g})$.

In traditional medicine practiced in southern Oaxaca, the anti-inflammatory and analgesic properties of $S$. scandens are of common use in the treatment of dental problems, so this plant represents a natural product in isolated communities where medical services are scarce or null (Cenobio García et al., 2021). On the other hand, due to its medical and nutritional uses, this plant helps supplement the income of families in these communities, so its trading is common in the regional markets.

The purpose of this work was to document the local indigenous knowledge about handling practices as well as nutritional and medicinal uses of $S$. scandens, using a field survey and applying interviews in a community of southern Oaxaca, Mexico. The intent is to describe the therapeutics associated with the findings.

\section{MATERIAL AND METHODS}

\subsection{STUDY AREA}

The field work was done in the geopolitical district of Miahuatlán, in southern mountain range region of Oaxaca, Mexico. The study was conducted in the municipal market and the "tianguis" (an itinerant open street market installed one day a week) of Miahuatlan de Porfirio Diaz (16 $19^{\prime} 41^{\prime \prime} \mathrm{N}$, 96 35'48" W, $1600 \mathrm{~m}$ a.m.s.1.), where the sale of Salmea scandens is carried out. In addition, the study covered the community of La Cienega, municipality of San Andrés Paxtlan (1607'12.72" N, 96¹8'57.24" W, $2407 \mathrm{~m}$ a.s.1), where the indigenous knowledge about this species was documented (Fig. 1). The population of La Cienega harbors 212 habitants; 97\% of them are Zapotec indigenous, with 17.3\% of analphabetism and 4.4 years of average schooling (INEGI 2018; INPI 2015). The municipality presents high levels of marginalization, poverty and social lag, and is part of the priority rural attention zone and the national Crusade Against Hunger (SEDESOL 2017). In La Cienega, orchards and plots where the plant grows were visited and two varieties (morphotypes) of S. scandens were registered. Local people 
differentiate both morphotypes by its cortex color, black or white, locally known as "palo de chile negro" (black chili stick) and "palo de chile blanco" (white chili stick), respectively. Following the recommendations of Bedford and James (1995), plant specimens were collected from both morphotypes, they were taxonomically determined and deposited in the Instituto Politécnico Nacional Interdisciplinary Research Center for Regional Integral Development, Oaxaca's (OAX) herbarium collection (vouchers Maciel-Amador O. 01, 02).

Figure 1. Geographical localization of the study zone, La Cienega, Municipality of San Andrés Paxtlan, Oaxaca, México.

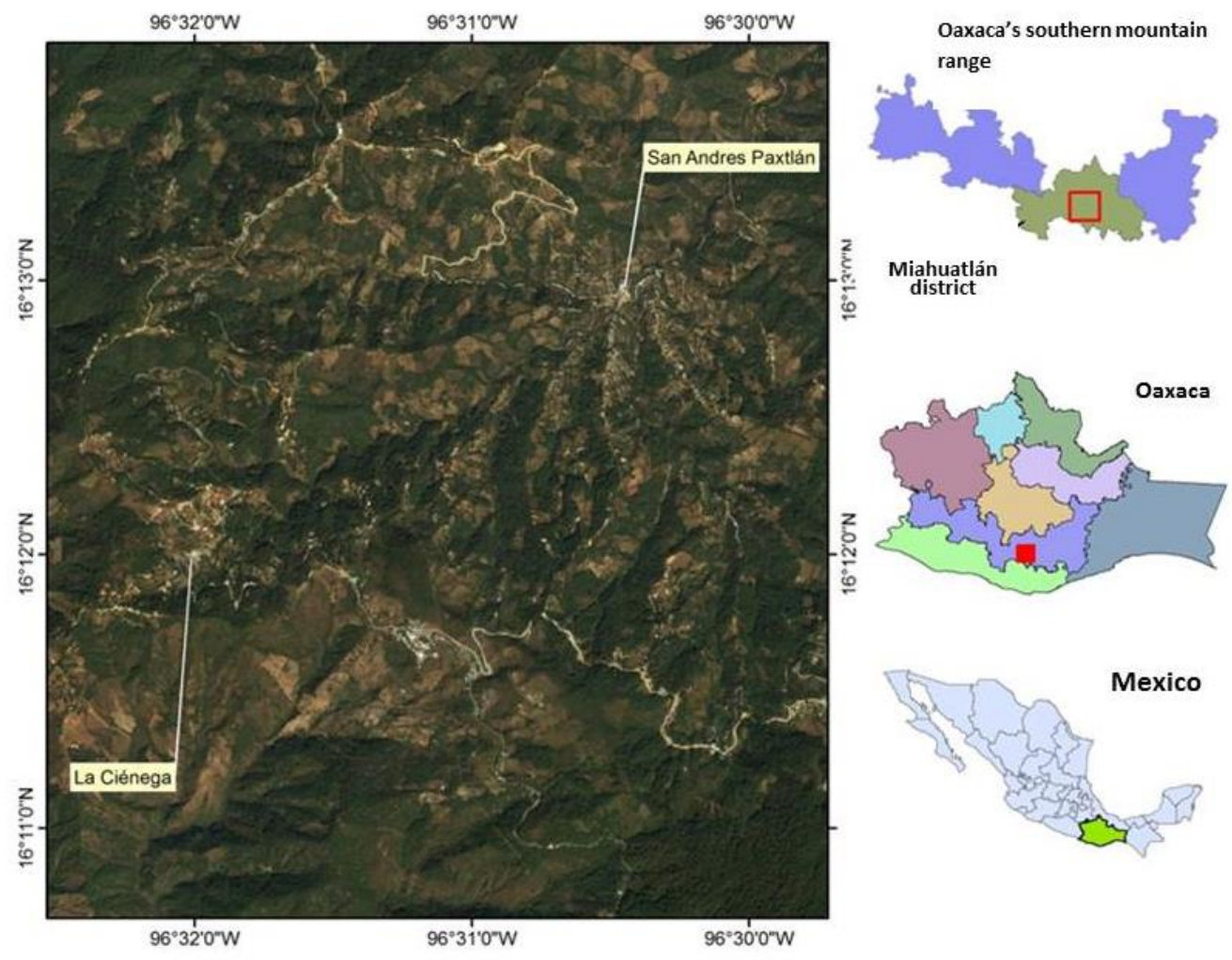

\subsection{FIELD WORK AND INTERVIEWS}

The municipal market and the "tianguis" of Miahuatlan de Porfirio Diaz were visited in September and October of 2018. Here, the way in which the specimens are traded, localities where the plant is harvested, people involved in this trade, and their uses for this species were documented. Regular visits to La Cienega community, at least with monthly recurrence, were conducted between September 2018 and March 2019; here, two key informants were identified (referred by the community as connoisseurs and plant sellers). The two informants were asked for their permission to do an open interview (based on the formulation of open questions so that the person interviewed can express all the information that allows the interviewer to know the subject of study). The objective was to document the traditional 
indigenous knowledge about $S$. scandens by interviewing the key informants using a format that followed Gary (1995), Hurtado-Rico and Rodríguez-Jiménez (2006) and Magaña et al. (2010) to obtain information about the plant's management practices as well as its medicinal and nutritional uses in the community. It is necessary to mention that the field work was carried out under the code of ethics of

To document local indigenous knowledge about $S$. scandens, and semi-structured interview was applied in La Cienega (Guber 2011; López-Roldán and Fachelli 2015), using the format presented in Appendix 1. The questions focused on: i) interviewees' socio-economic factors (age, gender, education, language, occupation, birthplace), ii) knowledge about management and uses of the species, and iii) the therapeutics practices used for the species. Twenty-four persons were interviewed (11.2\% of La Cienega's total population), according to the recommendation of Aguilar-Barojas (2005). People over 18 years old, both genders, were invited to collaborate in this study, regardless of the level of education or work activity and without any commitment or compensation to participate. We understand our responsibility to respect and protect indigenous peoples and their biocultural knowledge so the purpose of the work was communicated during each interview and consents were requested to publish the results. The study followed the ethical standards of the International Society of Ethnobiology (2006), so all participant names remained anonymous for purposes of privacy and dignity.

\section{RESULTS AND DISCUSSION}

\subsection{SOCIO-ECONOMIC ASPECT OF INTERVIEWEES}

The age of the 24 persons interviewed in La Ciénega, 10 men and 14 women, ranged from 23 to 81 years old. Twenty-two of them were born in the community, while the other two arrived here from two nearby communities. Regarding level of schooling, $17 \%$ of the informants did not have access to education: $58 \%$ had primary school, $8 \%$ secondary school, and $17 \%$ high school. About the economic activity of the informants, half of them are housewives, while the rest works in field activities (carpenters or students did not have statistically significant representation). Most interviewees (96\%) are bilingual, speak Spanish and Zapotec and, according to CDI (2006) and INEGI (2018), are classified as indigenous, while the rest only speaks Spanish (Table 1). Concerning to how knowledge about the uses of S. scandens was acquired, all respondents reported learning it from their parents. 
Table 1. Socio-economic data of the people interviewed in the community La Cienega, municipality of San Andrés Paxtlán, Oaxaca, Mexico, on the use of Salmea scandens. M, male; F, female; NE, not schooling; EEP, primary education; EES, secondary education; EMS, high school; S-Z, Spanish-Zapotec; S, Spanish; E, edible; M, medicinal; CO, consumption; CO$\mathrm{V}$, consumption-sale.

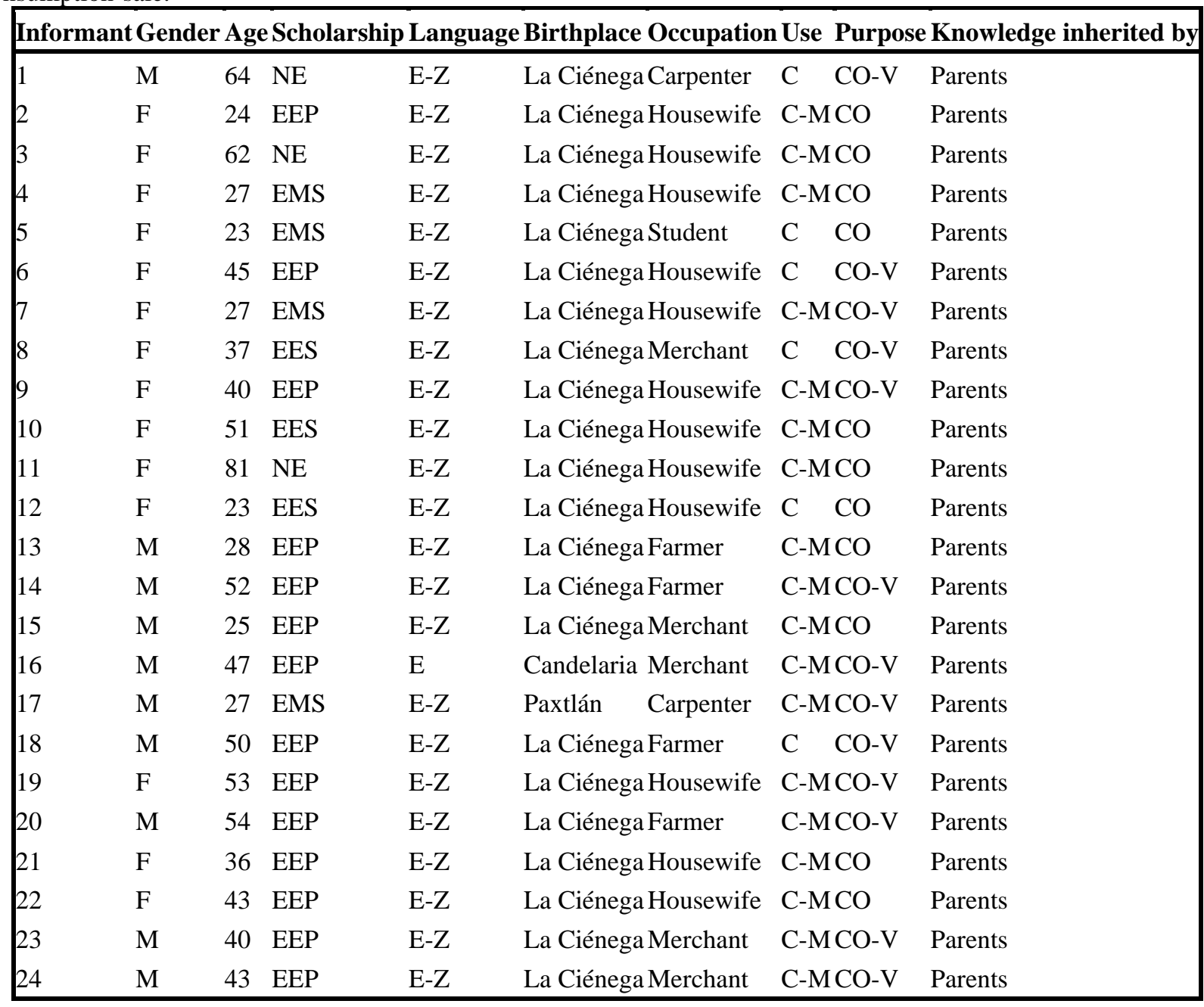

\section{a. Management of Salmea scandens}

All the people interviewed reported being collectors of $S$. scandens in La Ciénega. The families of these informants have shrubs of the species in semi-agricultural conditions in orchards or plots of their property. All informants mentioned that they give a nutritional use to the collected material, but a little more than half of them (54\%) destines their collect for sale. On the latter scenario, the same collector can sell his product in the markets of Miahuatlán de Porfirio Díaz or sell it to a merchant (intermediary who is usually a relative of the collector). The collect of chili stick consists of cutting pieces in branches, 30$50 \mathrm{~cm}$ long and $1-5 \mathrm{~cm}$ in diameter. The harvest takes place in the morning and the tool used is known as machete; both men and women, over 18 years of age and with the ability to enter the area where the plant is located, perform this activity. When cutting, the primary branches of the shrubs are preserved (to guarantee the continuity of the growth of the pruned specimens) and secondary or tertiary branches with a 3 to $5 \mathrm{~cm}$ diameter are cut if the branches have bark. With respect to the chili stick trading, the unit of 
sale is a bag containing between 30 and 50 branches, weighing 30 to $40 \mathrm{~kg}$. The collector sells each bag to a merchant who, depending on the weight, a bag can reach a price of up to 25 USD. If the collector sells his own product in the market, without an intermediary, then each bag reaches a higher price, between 25 and 35 USD. The quantity of bags that the collector can obtain depends on the number of plants he has, as well as on the demand for the product in the market. In summary, the commercialization of this plant represents additional income for the family economy of a community that is characterized by its high levels of poverty and isolation. Although this activity and the profits it generates are present during most of the year, they decrease in the dry months (January to May).

While S. scandens is collected and traded, collectors also carry out other activities that generate additional income such as beekeeping for honey production, or the management of aromatic, forest, medicinal and edible plants. These activities are conducted in their plots, which allow them to maintain their land, verify their crops, collect other plants of economic value, and mark the boundaries of their land.

\section{b. Morphologic variation of Salmea scandens}

In the orchards and plots where $S$. scandens grows, two forms coexist, considered here as morphotypes. All interviewees affirmed that they recognize this variation and use a different name for each form, "white chili stick" and "black chili stick", herein named as white morphotype and black morphotype, respectively. Concerning the foliar and floral features, the two morphotypes are indistinguishable; the difference lies on the coloration of the cortex: the white morphotype has a whitish color cortex, while in the other morphotype the cortex is blackish (Fig. 2). Some authors have pointed out that $S$. scandens has morphological variation in its stems, leaves, and flowers, which has led to forms that exhibit some morphological differences and have been proposed as different taxa. However, Bolick (1991) considers $S$. scandens as a unique species that exhibits great variation throughout its distribution. A study in progress shows differences in the chemical composition of the essential oil of leaves and stems between the black and white morphotypes collected in La Ciénega. Thus, the differences in both morphotypes would be determined at the anatomical and phytochemical levels, which could reflect in a different biological activity between them. Additional studies are required to corroborate it. 
Figure 2. Salmea scandens morphotypes variation used in the study area: 1. Black chili stick, A) transverse cut of the stem B) longitudinal cut of the stem. 2. White chili stick, A) transverse cut of the stem B) longitudinal cut of the stem.

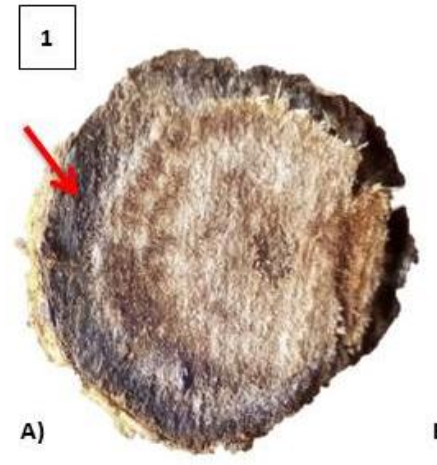

B)

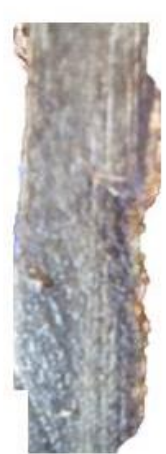

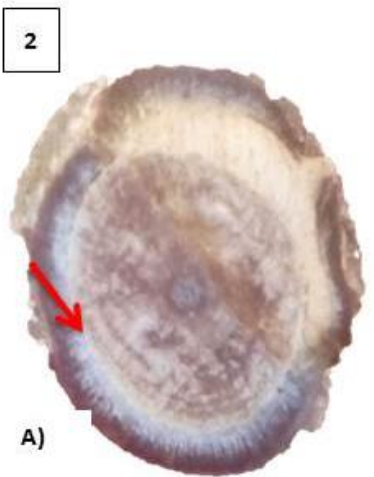

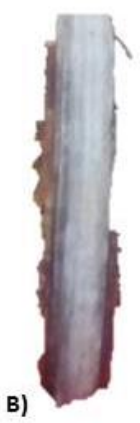

\section{c. Local indigenous knowledge of Salmea scandens}

From 24 informants reported knowing the edible use of the species, 18 of them (75\%) mentioned awareness of its medicinal use, while six of them did not know it. As food, S. scandens is used to season some of the traditional dishes of Oaxaca, such as beans and "chepiles" (soups and stews made with wild or cultivated herbs of the genus Crotalaria L., family Fabaceae). These food uses had been previously documented for the southern Oaxaca region (Luna-José and Rendón-Aguilar 2008; Villa-Ruano et al. 2015). However, here we report an additional edible use for the species, not as a seasoning but as the main ingredient of a different dish. In this case, the preparation method consists of using stems $5-10 \mathrm{~cm}$ long, which are boiled twice and seasoned with salt and garlic. At the end of the preparation, the branch pieces are removed, and the bark consumed by chewing or sucking until they lose its flavor. According to the women interviewed, knowledgeable about the process, double boiling makes detaching of the bark and digestion of the stems easier. When branches of the white morphotype are used, their bark detaches more rapidly than that of the black morphotype, but the latter has a spicier taste than the former, which makes the white morphotype preferable for consumption purposes in the community.

Pérez-José and García-Morales (2016) analyzed the nutritional content of S. scandens bark collected in southern Oaxaca, reporting the following values for a fresh sample: fiber (10.9\%), fat (2.9\%), protein $(4.9 \%)$ and potassium $(834.61 \mathrm{mg} / 100 \mathrm{~g})$; meanwhile, in a boiled sample the values were: fiber $(9.4 \%)$, fat $(2.5 \%)$, protein $(3.1 \%)$ and potassium $(505.53 \mathrm{mg} / 100 \mathrm{~g})$. The authors recommend the consumption of stems in fresh form due to their higher nutritional content. The high fiber and protein content in the species make it a healthy and easily available alternative to be included in the diet of a marginalized community that has been included in the program of the Crusade Against Hunger by the Mexican government (SEDESOL 2017).

With respect to the medicinal use for S. scandens, the informants mentioned the use of bark and leaves of both morphotypes for the treatment of toothache, "clavillo", a local term to refer to a "nacido" 
("born" or boil), and gastritis (Table 2). The informants did not mention a preference for any morphotype for medicinal use. For toothache, the treatment consists of chewing a piece of fresh bark with the dental pieces where the discomfort occurs until the spicy taste fades, when an analgesic effect occurs. For boils, the treatment consists of grinding about 10 leaves and placing the macerated material as a poultice on the affected area of the skin and covering it with a bandage. It is recommended to apply this treatment daily until the wound disappears. To treat gastritis, an aqueous infusion with stem pieces is prepared, which is then drunk constantly instead of water until relief is felt in the affected gastric region.

The medicinal use of $S$. scandens registered here as well as the one reported in the literature, relates to pathologies where inflammation is implied, such as gastritis and odontalgia, which highlights the presence of anti-inflammatory and analgesic properties in the species. This species is also used for other health issues such as muscle aches, vaginal bleeding, coughing, hernias, and urinary conditions (Guzmán 2010; Pérez-José and García-Morales 2016), but none of these uses was recorded in the present study. This suggests that $S$. scandens has pharmacological potential in the treatment of dental problems, since people interviewed reported dental pain mitigation as the main therapeutic use they give to the plant. It is recommended to conduct studies that allow the evaluation of the anti-inflammatory and analgesic activity of the species in the treatment of odontalgias, which could lead to the discovery of new natural alternatives in the attention of a health problem with high prevalence among rural communities.

The presence of $\mathrm{N}$-alkyl amides with anti-inflammatory properties has already been reported in this plant (Bohlmann et al. 1985; Boonen et al. 2012; Villa-Ruano et al. 2015), as N-isobutyl- (2E, 4E, 8Z, 10 E / Z) -dodecatetraenamide, and Deca-2Z-eno-6,8-diinoic acid phenylethylamide.

The use of $S$. scandens for the treatment of boils (clavillo) and dental problems represents medicinal applications not previously reported for the species. However, the use of the plant for conditions such as gastritis and odontalgia had already been documented (Guzmán 2010; Pérez-José and GarcíaMorales 2016). This information is relevant as it allows for a proper selection of the type of plant material and the best suitable means to obtain the extracts for an evaluation of the pharmacological properties of the species, being guided by the experiences and traditional knowledge of a community where the plant currently has medicinal uses.

Table 2. Medicinal uses of Salmea scandens registered in La Ciénega, municipality of Andrés Paxtlán, Oaxaca, Mexico.

\begin{tabular}{lllll}
\hline $\begin{array}{l}\text { Health } \\
\text { problem }\end{array}$ & $\begin{array}{l}\text { Part of the } \\
\text { plant }\end{array}$ & Way of use & Treatment & Patient \\
\hline $\begin{array}{l}\text { Odontalgia } \\
\text { (Toothache) }\end{array}$ & Bark & Chew & $\begin{array}{l}\text { A piece 3-5 cm long } \\
\text { by 1-2 cm wide, chew } \\
\text { it until the pain } \\
\text { subsides. }\end{array}$ & $\begin{array}{l}\text { Over } 18 \text { years } \\
\text { Grind 10 leaves, place }\end{array}$ \\
$\begin{array}{l}\text { Furuncle } \\
\text { (Clavillo) }\end{array}$ & Leaf & Cataplasm & $\begin{array}{l}\text { On ther wound and } 18 \\
\text { on years }\end{array}$
\end{tabular}


dress it. Do it after each bath until the boil decreases.

Boil 3-5 stems $20 \mathrm{~cm}$ long by $2-3 \mathrm{~cm}$ wide.

Gastritis (heartburn)
Bark infusion
Once boiled strain the

water and take it daily until the discomfort subsides
Over 18 years old

\section{CONCLUSIONS}

Salmea scandens is a plant valued for its nutritional and medicinal uses as well as a commercial resource in the area of study for which there is local indigenous knowledge about its management and consumption. Such knowledge is transmitted across generations as part of a biocultural heritage. In the study area, the management of the species is carried out at a family level, based on its harvesting and subsequent consumption or sale in traditional markets of the area. This activity generates an additional benefit to the economy of the families of this indigenous and marginalized community in the state of Oaxaca.

The medicinal uses registered here for $S$. scandens are related to health conditions that involve an inflammatory process, such as odontalgia. This represents a potential pharmacological resource for the research of new natural products in the treatment of dental problems. In the area of study there are two morphotypes recognized by the local population (black and white) for $S$. scandens. For food preparation purposes, there is preference for one of the morphotypes (white), but there is no preference for medicinal uses.

\section{AUTHORS CONTRIBUTION}

OMA carried out the fieldwork, obtained the management information, conducted the interviews, organized and analyzed the information, and drafted the first version of the manuscript. LLR designed the study, proposed its goals, and made corrections to the manuscript. RS analyzed the results of the interviews and contributed to the writing of the manuscript. NMPB proposed revisions and corrected the manuscript.

\section{DECLARATION OF COMPETING OF INTEREST}

The authors declare no conflicts in the publication of this work.

\section{KCKNOWLEDGEMENTS}

To the informants who participated in the study. 


\section{FOUNDING}

To the National Council of Science and Technology (CONACYT) for the scholarship granted to OMA.

To the National Polytechnic Institute for the economic support for research granted to NMPV (SIP20195374). 


\section{REFERENCES}

Aguilar-Barojas, S. (2005). Fórmulas para el cálculo de la muestra en investigaciones de salud. Salud de Tabasco. 11, 333-338.

Aguilar-Santelises, R., del Castillo, R.F. (2015). Demographic and socio-economic determinants of traditional plant knowledge among the Mixtecs of Oaxaca, Southern Mexico. Hum Ecol. 43, 655-667. https//doi.org/10.1007/s10745-015-9772-Y.

Bedford, D., James T. (1995). Collection, Preparation and Preservation of Plant Specimens. $2^{\text {nd }}$ ed. Royal Botanic Gardens Sydney, Sydney, Australia.

Boege, E. (2008). El Patrimonio Biocultural de los Pueblos Indígenas de México. Hacia la Conservación in situ de la Biodiversidad y Agrodiversidad en los Territorios Indígenas. Instituto Nacional de Antropología e Historia, Comisión Nacional para el Desarrollo de los Pueblos Indígenas, México.

Bohlmann, F., Hartono, L., Jakupovic, J. (1985). Highly unsaturated amides from Salmea scandens. Phytochemistry, 24, 595-596. https://doi.org/10.1016/S0031-9422(00)80774-8.

Bolick, M.R. (1991). Systematics of Salmea DC. (Compositae: Heliantheae). Syst Bot 16, 462-477. https://doi.org/10.2307/2419337.

Boonen, J., Bronselaer, A., Nielandt, J., Veryser, L., de Tré, G., de Spiegeleer, B. (2012). Alkamid database: Chemistry, occurrence and functionality of plant N-alkylamides. J Ethnopharmacol, 142, 563590. https://doi.org/10.1016/j.jep.2012.05.038.

De Feo, V. (2003). Ethnomedical field study in northern Peruvian Andes with particular reference to divination practices. Journal of Ethnopharmacology 85(2-3), 243-256. https://doi.org/10.1016/S03788741(03)00017-5.

Cenobio García, F. de J., Casillas Enríquez, J. D., Cázquez Sandrin, G., Garza Saldaña, O. F., \& Benítez Herrera, A. E. (2021). Características clínicas y epidemiológicas de la COVID-19 en las regiones indígenas de México Clinical and epidemiological characteristics of COVID-19 in the indigenous regions of Mexico. South Florida Journal of Development, 2(4), 5068-5080. https://doi.org/10.46932/sfjdv2n4-009

Carnevali, G., Tapi, J.L., Duno, R., Ramírez, I.M., Can, L., Hernández, S., Castillo, S., Castillo, A. (2012). La flora de la Península de Yucatán Mexicana: 250 Años de conocimiento florístico. Biodiversitas, 101, 6-10.

García-Vargas L.A. (2018). Radiografía Demográfica de la población indígena en Oaxaca. Población Indígena, 41, 7-20.

García-Mendoza, A.J. (2004). Integración del conocimiento florístico del estado. In García-Mendoza A.J., Ordóñez M.J., Briones-Salas M.A, (eds.), Biodiversidad de Oaxaca. Instituto de BiologíaUniversidad Nacional Autónoma de Mexico, Fondo Oaxaqueño para la Conservación de la NaturalezaWorld Wildlife Found, México. pp. 305-325,

Grossman, J.M. (2003). Exploring farmer knowledge of soil processes in organic coffee systems of Chiapas, Mexico. Geoderma, 111, 267-287. https://doi.org/10.1016/S0016-7061(02)00268-9

Guber, R. (2011). La Etnografía. Método, Campo y Reflexividad. Siglo XXI Editores, Buenos Aires. 
Guzmán G.P. (2010). Exploración, aprovechamiento y validación experimental de plantas con efecto antiinflamatorio de la Sierra Madre Oriental de San Luis Potosí. Master in Sciences thesis. Programa Multidisciplinario de Posgrado en Ciencias Ambientales, Universidad Autónoma de San Luis Potosí. San Luis Potosí, México. 79 p.

Hurtado-Rico, N. E., Rodríguez-Jiménez, C. (2006). Estudio cualitativo y cuantitativo de la flora medicinal del municipio de Copándaro de Galeana, Michoacán, México. Polibotánica 22, 21-50.

Instituto Nacional de Estadística, Geografía e Informática. (2018). Banco de indicadores. Instituto Nacional de Estadística, Geografía e Informática. https://www.inegi.org.mx/app/buscador/default.html?q=poblaci\%C3\%B3n+san+andres+paxtlan\#tabM Ccollapse-Indicadores (consulted May 01, 2019).

Instituto Nacional de los Pueblos Indígenas (INPI). (2015). Indicadores Socioeconómicos de los Pueblos Indígenas de Méxicohttps://www.gob.mx/inpi/articulos/indicadores-socioeconomicos-de-los-pueblosindigenas-de-mexico-2015-116128 (consulted octubre 31, 2019)

International Society of Ethnobiology. (2006). Code of Ethics of the International Society of Ethnobiology (with additions in 2008). http://ethnobiology.net/code-of-ethics/.

López-Roldán P., Fachelli, S. (2015). Metodología de la Investigación Social Cuantitativa. Universidad Autónoma de Barcelona, Barcelona.

Luna-José A.L., Rendón-Aguilar, B. (2008). Recursos vegetales útiles en diez comunidades de la sierra madre del sur, Oaxaca, México. Polibotánica, 26, 193-242.

Luna-José A.L., Rendón-Aguilar, B. (2012). Traditional knowledge among Zapotecs of Sierra Madre del Sur, Oaxaca. Does it represent a base for plant resources management and conservation? J Ethnobiol Ethnomed 8, 24. doi: 10.1186/1746-4269-8-24

Magaña-, M. A., Gama, L. M., Mariaca, R. (2010). El uso de las plantas medicinales en las comunidades maya-chontales de Nacajuca, Tabasco, México. Polibotánica 29, 213-262.

Martin, G.J. (1995). Ethnobotany. A methods manual. Chapman and Hall, United Kingdom ISBN 9780-412-48370-7.

Martínez, M. (1994). Catálogo de nombres vulgares y científicos de plantas mexicanas. Fondo de Cultura Económica. Ciudad de México. 1248 p.

Ordóñez, M. J., Rodríguez, P. (2008). Oaxaca, el estado con mayor diversidad biológica y cultural de México, y sus productores rurales. Ciencias 91, 54-64.

Pérez, J., García-Morales. (2016). Estudio etnobótanico y contenido nutrimental de Salmea scandens en Buena Vista Loxicha, Pochutla, Oaxaca. Bachelor thesis, Instituto Tecnológico del Valle de Oaxaca. Santa Cruz Xoxocotlán.

Secretaria de Desarrollo Social (SEDESOL). (2017). Informe anual sobre la situación de pobreza y rezago social 2017. Oaxaca, San Andrés Paxtlán (20095). Subsecretaria de Planeación, Evaluación y Desarrollo Regional. Ciudad de México. http://diariooficial.gob.mx/SEDESOL/2016/Oaxaca_095.pdf (consulted October 28, 2019). 
Serrano-Carreto, E. (2006). Regiones Indígenas de México. Comisión Nacional para el Desarrollo de los Pueblos Indígenas, Programa de las Naciones Unidas para el Desarrollo, Mexico.

Tortoriello J., Meckes-Fischer M., Villareal, M. L., Berlin, B., Berlin, E. (1995). Spasmolytic Activity of medicinal plants used to treat gastrointestinal and respiratory diseases in the highland of Chiapas. Phytomedicine 2, 57-66. https://doi.org/10.1016/S0944-7113(11)80050-4.

Villa-Ruano N., Pacheco-Hernandez, Y., Rubio-Rosas E., Lozoya-Gloria E., Mosso-González C., Ramón-Canul L. G., Cruz-Durán R. (2015). Essential oil composition and biological/pharmacological properties of Salmea scandens (L) DC. Food Control, 57, 177-184. https://doi.org/10.1016/i.foodcont.2015.04.018.

Villa-Ruano, N., Zurita-Vásquez, G.G., Pacheco-Hernández, Y., Betancourt-Jiménez, M.G., CruzDurán, R., Duque-Bautista, H. (2013). Anti-lipase and antioxidant properties of 30 medicinal plants used in Oaxaca, México. Biol. Res. 4, 153-160. doi: 10.4067/S0716-97602013000200006.

Villaseñor, J.L., (2016). Checklist of the native vascular plants of Mexico. Rev. Mex Biodiver. 87, 559902. http://dx.doi.org/10.1016/j.rmb.2016.06.017

Villaseñor, J.L., (2018). Diversidad y distribución de la familia Asteraceae en México. Bot Science 96, 332-358, http://dx.doi.org/10.17129/botsci.1872 
Figure 1. Geographical localization of the study zone, La Cienega, Municipality of San Andrés Paxtlan, Oaxaca, México.

Figure 2. Salmea scandens morphotypes variation used in the study area: 1. Black chili stick, A) transverse cut of the stem B) longitudinal cut of the stem. 2. White chili stick, A) transverse cut of the stem B) longitudinal cut of the stem. 